\title{
Settlement Renewal Strategies Based on Physical and Non-Physical Characteristics in Kalisari Fishermen Settlement, Surabaya-Indonesia
}

\author{
Dahliani $^{1,4}$, Susy Budi Astuti ${ }^{2,4}$, Ratna Darmiwati ${ }^{3,4}$, Happy Ratna Sumartinah ${ }^{4}$, Johan Silas ${ }^{4}$ \\ ${ }^{1}$ Department of Architecture, Universitas Lambung Mangkurat, Banjarmasin, Indonesia \\ ${ }^{2}$ Department of Interior Design, Institut Teknologi Sepuluh Nopember, Surabaya, Indonesia \\ ${ }^{3}$ Department of Architecture, Unika Darma Cendika, Surabaya, Indonesia \\ ${ }^{4}$ Department of Architecture, Institut Teknologi Sepuluh Nopember, Surabaya, Indonesia
}

\section{Email address:}

lily.unlambjm@gmail.com (Dahliani),kreasisusy@yahoo.com (S. B. Astuti), ratnadarmiwati@gmail.com (R. Darmiwati), happyratna@yahoo.com (H. R. Sumartinah),johan.silas@yahoo.com (J. Silas)

\section{To cite this article:}

Dahliani, Susy Budi Astuti, Ratna Darmiwati, Happy Ratna Sumartinah, Johan Silas. Settlement Renewal Strategies Based on Physical and Non-Physical Characteristics in Kalisari Fishermen Settlement, Surabaya-Indonesia. Humanities and Social Sciences.

Vol. 3, No. 3, 2015, pp. 102-110. doi: 10.11648/j.hss.20150303.11

\begin{abstract}
Surabaya is developed to function as the nation's center of development for the main area $\mathrm{C}$, covering areas in the east and north of Indonesia, as the nation's target for development in escalating the society's living standards, enhancement in city development in the fields of industry, trading, maritime, garrison, and tourism. With the development goals directed towards the availability of work, homestead, kinship, pleasure and education. Surabaya must prepare means and facilities to support Surabaya as a metropolitan and maritime city, however due to the rural circumstance characteristics, it is time for Surabaya to step in (to integrate between urban and rural) to be the second largest city after Jakarta.The scope the study in this research is identification that is conducted in a fisherman's settlement in the area of Kalisari Mulyorejo, Surabaya. The identification covers physical and non-physical aspects of location of the area, area's position, structure and city plan and its surroundings, the environment and buildings' condition, land use, the availability of infrastructure and means, inhabitants' characteristics covering demography, social economic and culture condition. The reseach method is conducted by inventory of data, using the observation technique, interview, documentation; moreover visual observation (primary data/ physical aspect, economy, social, culture from respondents dan secondary data are obtained from supporting literatures); by solving area's space planning technique by managing the city's and shore potential where the fishermen's settlement lies in between. The use of theory is related to the fishermen's settlement, sense of place dan new urbanism, because the area of fishermen's settlement is located between the city and shore.Result of the research is a strategy concept in efforts to renewal the fishermen's settlement in Kalisari Surabaya based on physical and non-physical characteristics.
\end{abstract}

Keywords: Fishermen's Settlement, Physical Characteristics, Non-Physical Characteristics

\section{Introduction}

\subsection{Background}

Based on the existing potential and characteristics, Surabaya is developed to function as the nation's center of development for the main area $\mathrm{C}$, covering areas in the east and north of Indonesia, as the nation's target for development in escalating the society's living standards, enhancement in city development in the fields of industry, trading, maritime, garrison, and tourism.
The land in Surabaya is not fully urban, because there are areas with rural use such as paddy field, moor, ponds and coastal forests. The rural use of land are mostly found in the west, south-west and eastern part of Surabaya. According to the main data map of the government of Surabaya, the use of land in Surabaya consists of $12.474,42$ ha or $38,89 \%$ of housing, whereas the land use for other purposes are still large, which consist of $6.410,68$ ha or $19,98 \%$ pond.

The condition shows that the activity in Surabaya is dual, which is urban and rural. It is related with the environment which is a hilly topography at the werstern part of Surabaya 
and shore at the eastern part of Surabaya, which causes Surabaya to develop naturally at the northern axis following the flow of the Kali Mas river, causing more density than the west and eastern part of Surabaya. To generate an even development and decrease hindrances in the cental area, the government of Surabaya sets a development strategy with a renewal program in the center and expands it to the west and eastern area of Surabaya.

\subsection{Study Purpose}

Surabaya as a national center of development and regional's to East Java, it stimulates Surabaya to prepare various means and facility to support Surabaya as a metropolitan, yet on the other hand, the environmental condition of the city is partly rural. It is for this reason that this study/research is conducted, to investigate the condition of the city, specifically the rural settlement area such as the the east coast, which cover salt pond / fishermen. Moreover to give concideration to Surabaya to aim towards a metropolitan, combining the function of urban and rural.

\subsection{Reseach Scope}

The scope the study in this research is identification that is conducted in a fisherman's settlement in the area of Kalisari Mulyorejo, Surabaya. The identification covers physical and non-physical aspects of location of the area, area's position, structure and city plan and its surroundings, the environment and buildings' condition, land use, the availability of infrastructure and means, inhabitants' characteristics covering demography, social economic and culture condition. As for the analysis consists of analyzing the existing condition especially the settlement's elements to obtain the renewal strategy based on the local characteristics.

\section{Literature Study}

\subsection{Fishermen's Settlement}

The Fishermen's settlement is a settlement area with basic means and facility in which most of the inhabitants are people who are occupied as fishermen and have the access and bond between the locals and the sea as a source to earn living, however lots are also still related to land (Umbara, 2003 dalam Nasir 2014). Darmiwati (2001), stated that fishermen settlement usually grows naturally without spacial control. Therefore the housing grows and develops unorganizedly.

Basri (2009), in Supriyanto (2001), stated that the problem in fishermen's settlement is that they do not yet meet the standards of health, comfort, security, order, aesthetic and environmental awareness.

Due to city's development, its existence is not far away from city's facilities. According to Basri, a fishermen settlement that is located in a city should be retained because of the additional value it brings to the city. Turner (1972), stated that the location consideration of housing are the easeness of reach the workplace and the unity of community and also access to environmental means and facilities.
Najib (2008), stated that traditional fishermen always look for fish at areas that are long well knowned for years, and it is difficult for the fishermen to enter foreign areas. Syahriarto (2013) in Nasir (2014), stated that fishermen should have facilities to support the activity; covering: a.) A fish auction, is a place for trading fish with an auction system where activities such as checking weight, organize the fish by its types in baskets.or putting the fish on the floor ready to be put for auction, moreover packing with with an ice box for fish to be frozen. The fish auction should be located nearby the dock for the easeness of distributing the fish from the boat. b) Boat moorings, is a place where the boats lean on before and after the fish are taken out of the boat. The location shoud be nearby the fish auction. There are two kinds of boat moors, which is the side moor (used in deep water) and dock moor (used in shallow water). c) A place to dry the fish in the sun, used for drying fish as a process of preservation; it should be an open space with direct access from the sun, preferably there should be holes for water to drip so that the fish will dry quicker, it should also be clean and be made an access for the waste, moreover there should also be a drainage system so that the water won't stagnate and it should also be accessible for supervision and control.

\subsection{Fishermen's Settlement Renewal}

According to "Fishermans Bend Urban Renewal Area" 2013, there are 10 (ten) renewal strategies for the fishermen settlemen: The creation of $21 \mathrm{st}$ century jobs, The timely provision of infrastructure, A place that is easy to get around, A vibrant, mix of uses and activities, Distinctive and diverse neighbourhoods, A great place for families, A high quality built environment, Smart environmental solutions, Environmental constraints addressed, Strong partnerships and effective governance. Those ten strategies are expected to be developed in the fisermen's settlement, and be adapted to the characters of its settlement, physically and non-physically. The settlement renewal should also pay attention to the concept of "New Urbanism" and "Urban Planning" so that it could unite with the city's government plans, which is by improving the city using traditional environment principles, for example in walking (walkable) to be able to reach facilities without undergoing heavy traffic, mix-used areas means and facilities in the same zone so it is easily accessed by walking (Kwuanda, 2001; Kartz, 1992 in Marwati, 2013).

The concept of New Urbanism is supported by "smart growth" principles, which are: Mixed land uses; Compact building design A range of housing opportunities and choices; Walkable Neihbourhoods; Distinctive, attractive communities with a strong sense of place; Preservations of open spaces, farmland, natural beauty, and environmental area; Development direted toward existing communities; A variety of transportation choices; Predictable, fair, and cost effective development; Community and stakeholder collaborations in development decisions (Ernawi,2012). These ten principles of "smart growth" could be a reference for the renewal of fishermen's settlement. The main idea of this concept is paying attention to the physical condition of the settlement i.e. 
the environmental condition, building, means and facilities,; and also to its non-physical aspects such as its social economics and the community's culture. The participation of the society plays an important part in the renewal program.

A settlement renewal is closely related to improving the quality of the environment of the settlement. The quality of the environment can be physically seen from the houses. Silas (1993) explained the concept of the existence of a home, in its establishment there should be unity, wholesomeness dan balance between the human being, house and the environment so that there is a dynamic coherence between the house and its surroundings and also sustainable and beneficial. The existence of a house could be sustainable if the inhabitants can meet the needs to ensure the house's physical development and economical needs within the household. Turner (1972) states that the inhabitant plays an important part on decising on the house's development, in accordance to their economical capability.

\section{Research Methods}

Techniques and modes of collecting data in organizing the study, consists of:

a. Data inventory through survey: interview, documentation, customized with research purposes.

b. Data inventory through visual observation: Obtained data include primal and secondary data. Primal data is obtained from the direct sourcesource (respondents in the area of fishermen settlement in Kalisari), which consist of:

1. Data/Physical Information:

Development design information, covering: Enviroment condition, physical means and facility and environmental facility, building, ownership, housing status, density, hydrology and landscape (groundwater condition, drainage system, capacity of land) environmental hindrances (water, air and soil contamination)

2. Data / Economical Information:

The population's economical potential (skills, business opportinities, work efficiency, work colerationi kerja and its benefits, purchasing power of residents), residents economical needs.

3. Data / Socio-Culture Information:

Informasi on residents' habits that affect the lifestyle of the community (habits, communication, kinship, religious relations) and also the habists that affect the environment (the habits of throwing garbage and household waste) etc.

Plan analysis, making use of various obtained data and information, furthermore grouping them by its types and needs; the process of analysis covers:

- Physical Development Analysis, to observe the potentials and obstacles to know as to how far the area could be developed; and by estimating the accomplishment strategy by observing the existing program.

- Socio-Culture and Economics Analysis, aims to reduce the risks of negative effects of area development, formulating community development policy, and seek forms of cooperation between the government, private institutions and the local community.

\section{Result and Discussion}

The quality of a settlement can be assessed by its physical and non-physical characteristics. A settlement has a good criteria, if the physical and non-physical aspects are fulfilled. The physical aspects can be reviewed from the geographic location, the environment and built environment, and also the environmental means and facility. The non-physical aspects can be reviewed from its social, economical and cultural aspect. In the Indonesian agenda 21 , it is stated that there should be a coherence in social, functional and ecological aspects in the development of residence to improve the inhabitant's living quality

The fishermen settlement characteristics are reviewed based on physical and non-physical aspects, where these two aspects are inseperable in order to establish a good residence area and environment. Social, economical and cultural aspects should be cohesive with its environtment in order the residence to be functional and ecologic.

\subsection{Settlement Characteristics Based on Physical Aspects}

Administratively, the fishermen settlement in Kalisari is located at kelurahan Kalisari, Kecamatan Mulyorejo, Surabaya City, East Java Province. The fishermen settlement in at RW 5 RT 3, with study boundaries i.e. at the west side of Tempelrejo river, at the south the drainage of Kalisari Surabaya Timur which is side by side with Mulyosari Prima Utara Street, at the east is a salt pond area, and in the north is an empty lawn including Tempelrejo Tanggul Street.

Like commonly in Surabaya, the Kalisari settlement has a sloping topography. The Kalisari settlement unlike other fisherment settelement, is not located by the shore, it is located at a riverbank with a distance of $3 \mathrm{~km}$ from the sea.

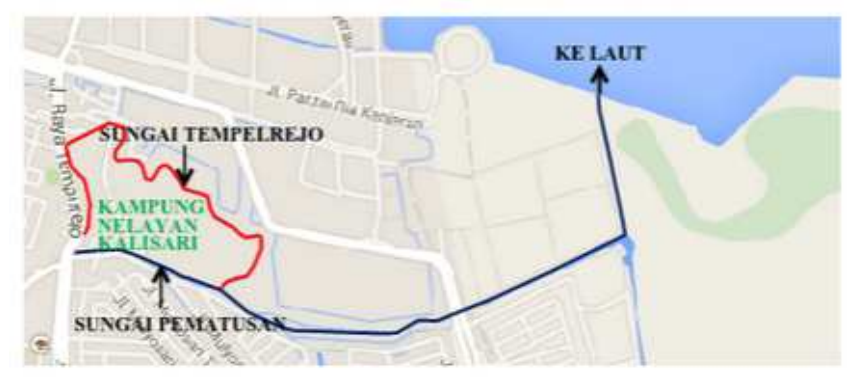

Source: Author

Picture 1. Fishermen Settlement Location to the Sea.

\subsubsection{Environmental Condition}

The Kalisari fishermen settlement has enviromental characterestic of being located at a riverbank Tempelrejo and the Kalisari drainage. The river and the drainage system are potential to the Kalisari fishermen settlement which can be developed to improve the area's potential. Besides the river 
and drainage, other characteristics of the area is a swamp that is used as a pond. There are two areas of pond that are still in use, these ponds are side by side with the drainage system in order to get water. These two ponds should be well maintained and should not be left dry. Moreover to add the owner's income, this area is used as an open space for the fishermen settlement's drainage sytem and rain water reservoirs.

Vegetation is also a characteristic of the settlement. Not all plant or vegetation can grow at Kalisari village, because of the salt containing soil. Only some specific areas can be cultivated. This condition leads to the settlement looking dull and arid. Plants that can grow well in this area are waru and kerzen. These two plant is potential to be an icon at the kalisari village. If these plants can be grown, then this village will look less dull and more beautiful.

From the analysis of the environmental condition as the basic physical condition of the fishermen settlement in Kalisari, there are three main physical characteristics, which is drainage and river, the pond areas and shore vegetation (that can live in salty water). This fishermen settlement can be developed through these three characteristics.

\subsubsection{Building Physical Condition}

The physical condition of the buildings can be seen from the inhabitants' houses, from the flooring condition, ventilation, room divisions, density of housing and density of population. People with permanent houses, mostly have good flooring condition, with slick cement or ceramic flooring, while the unpermanent houses also have cement flooring. All of the houses have flooring, none of them have ground flooring.

The divisions of rooms are to those of permanent housing with permanent owners (clear address and lawn status), is divided into 3 main functions; the guest room (also as the living room), bedroom and kitchen.

Meanwhile the permanent houses which rent rooms in size of $2,5 \mathrm{~m} \times 3 \mathrm{~m}$ or $3 \mathrm{~m} \times 4 \mathrm{~m}$ only has one room, what differs the room fuction the furniture within the room, the kitchen takes place at the terrace in front of the rented room. For unpermanent houses (with unclear lawn status and ownership), they are diided into 2 rooms, which is the livig room/public room and the bedroom. There are also unpermanent houses with the rented house room division system.

Mostly, the houses in the Kalisari fishermen settlement lack of ventilation, because of the density. Distances between the houses are very tight, so that it is difficult to create ventilation at the sides of the house. Ventilation is only available at the front side of the house (the living room or public room). To anticipate this problem, usually the walls doesn't meet the roof, it is rare to have ceiling, it is so that wind can circulate from between the roof.

The density of tall building and semi permanent buildings (made of plywood, zink, woven bamboo 'gedhek') Kepadatan bangunan yang tinggi dan bangunan semi permanen (triplek, seng, gedhek), creates an impression of dullness and makes it uncomfortable to look at with its unorganized condition. Moreover with tarpaullins or plastic or fabric that is used to shade and protect the house from the sun especially the rented rooms. The physical condition of the Kalisari village is dull due the unpermanent houses that are not well organized and the density. So that there should be a renewal and reorganizing in the Kalisari village.

\subsubsection{Availability of Means and Facility}

Means Condition can be analyzed from the availability of clean water, sanitation and waste water, waste, drainage sytem and roads.

The clean water source from PDAM is available at the Kalisari's fisherment settlement. Either that are owned by the inhabitant or bought by using a cart. Water tanks are available at some spots in this village. Buying clean water are usually done by those who are renting houses. Most of them do not own a PDAM pipeline. For washing, the inhabitants use well water.

Sanitation such as the bathroom/wc, a public bathroom/wc is available for renting residents, while residents with a permanent house owns their own. Disposal of domestic waste water are partly owned by residents with permanent houses, meanwhile those unpermanent houses dispose their domestical waste water in front of the house or an open area. Which creates a water puddle even just for temporary.

Rain water drainage are available at each side of the alley with the condition that the drainage are closed to keep it clean. Although there are some parts that are open. This rain water drainage heads to the river drainage. Garbage are already well managed. Every two days, the garbage collector would collect the garbage from each house with a price of Rp 4.000 for each family.

Facility Condition Observed from the availability of religious, education, health and economic facilities. This village owns two mushallas as religious facility and a place for the society to gather. Education, health and economics facilities such as a marketplace are available in the area and its surrounding, which is not far away from this village, $\pm 400 \mathrm{~m}$.

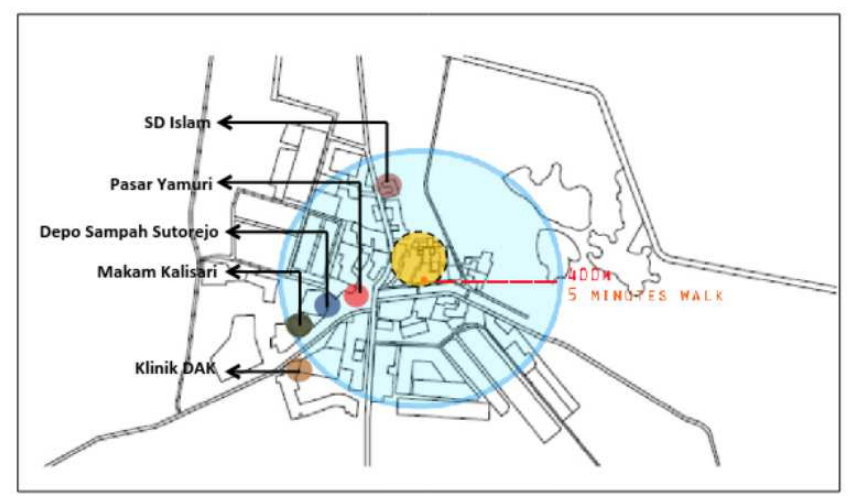

Source: Author's reconstruction based on field data, 2015

Picture 2. Availibility of Facility in the Village's Surrounding.

With a location that is not far away from environmental facility, the Kalisari fishermen settlement has a strategic location. The location fulfills the New Urbanism principle which is "walkability". The inhabitant dan fulfill their needs of public facility (economical, education, health and religious) 
by walking for 10 minutes in maximum time. However access to the facility is not free from heavy and dangerous traffic. Raya Mulyorejo Stree, Raya Tepelrejo Street and Kalisari Mulyorejo Street have busy traffic and no pedestrian road.

Facility Condition Specifically at the fish collector at the fishermen's settlement where the fish trading takes place. The location of the fish collector should be nearby the dock (boat moorings) to ease the distribution from ships. The activity uses a lot of water (sea water), so it is better to have access to clean water. The drainage system condition should also be in a good condition so that water will not puddle and produce a pungent odor.

Boat moorings that is located by the Kalisari drainage system is well organized. The most important in this location is the easeness of fish loading. By having a gradual leeve makes it easier to do the loading activity.

The place where drying of the fish takes place at the aleeve area is qualified, has direct access to open space, the sun and is not disturbed by circulation flow. However it is better if the fish drying place is clean by creating a drainage system for the waste water so that water won't create puddle and create a pungent odor.

\subsection{Settlement Characteristics Based on Non-physic Aspects}

\subsubsection{Lawn Status}

The Kalisari fishermen settlement consists of permanent residents, newcomer, seasonal residents. Picture 3 ilustrates the housing location and its lawn status.

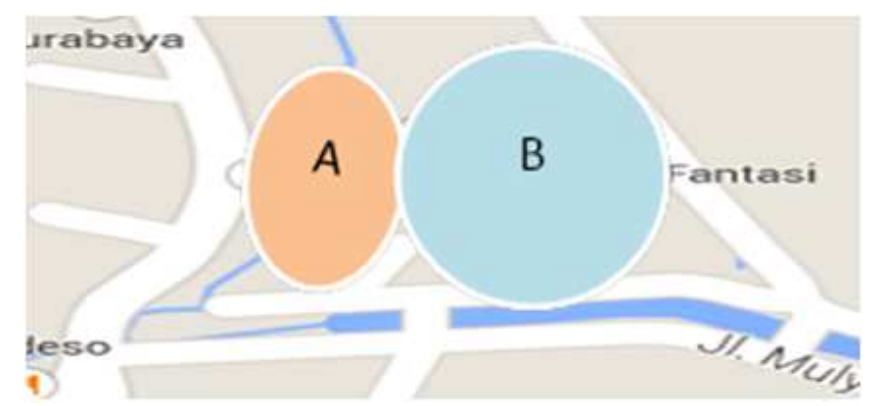

Source: authors's reconstruction based on field data, 2015

Picture 3. Settlement Area of Permanent Residents and Newcomers.

Area A, is inhabited by locals with certified lawn status. Most of the husbands are fishermen. The wife helps the husband at home (selling food/open up a shop). Area B is inhabited by newcomers and unpermanent residents (usually rents) come mostly from Madura and Lamongan. The lawn status is uncertified. For newcomers, the wife usually helps processing the fish. As for unpermanent residents, the husband usually sells food around or as construction worker, the wife as a maid at regencies nearby. Tabel 1 shows the occupation of the inhabitants of the Kalisari fishermen settlement.

Table 1. Occupation of the Inhabitants of the Kalisari Fishermen Settlement.

\begin{tabular}{llll}
\hline Inhabitants & Permanent & Newcomer & Unpermanent \\
\hline \multirow{3}{*}{ Husband } & - Fisherman & - Fishermen & - selling food aroud \\
& - Pond farmer, field and lawn farmer & - Pond farmer, field and lawn farmer & - construction worker \\
& - food stall & & - shop or factory employee \\
Wife & - necessities shop & - helps processing fresh fish and dried & - maid \\
& - tailor & fish & \\
\hline
\end{tabular}

Source: Observer's Data based on Field Source, 2015

*Info : Permanent Resident/Local: self-owned house, certified, historical bond with the village

Newcomer: self-owned, uncertified, at lawn that was previously used for pond

Unpermanent Resident : rented house

\subsubsection{Occupation}

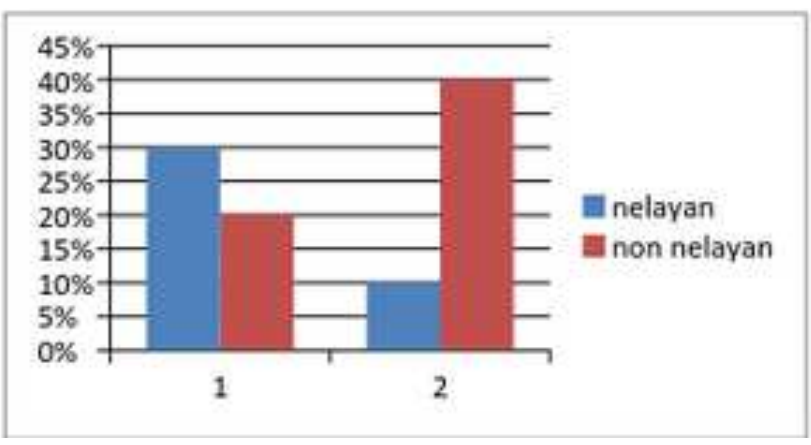

Source: author's data based on information from field source, 2015

Picture 4. Occupation Composition of Locals (1) and Newcomer (2).
Based on field information, the society consist $40 \%$ fishermer, $60 \%$ at other fields, show at picture 4 .

\subsubsection{Education}

The locals mostly didn't obtain formal education, they are pretty content to be a fisherman. Some children are seen not going to school, instead, they play kites or just gather at a street at school hours. The composition of the main family consist of 4-6 person. Quite a large number considering their low economical state, this condition makes it uncondusive to be developed. There are no formal education organizations, the only educational facility is Quran education center. Based on information mengingat taraf ekonomi yang kecil, kondisi ini menjadi tidak kondusif untuk maju. Lembaga pendidikan resmi tidak dijumpai di lingkungan kampung tersebut, yang ada hanya TPA (Taman Pendidikan Al Qur'an). Based on information source. 


\subsubsection{Social Economy}

The economic wheel is divided into fishermen's activity and merchant's activity. When it is fish hunting season, fishermen will go in groups or by themselves. A fisherman's income from fish hunting that are sold to fish collector that are then made into dried fish (salty fish), varies between Rp. 500.000-750.000/day for the fish boat owner, and Rp.150.000 -300.000 /day for non fish boat owner. The fish varies from belek batu, shrimp, gragu, bulu entok, teri and gatul (small teri). Products from the fish pond are bandeng, kakap, mujair dan belanak. The production of shrimp on average reaches Rp.7.000.000/3 month harvest season. With the calculation of each harvest with 2 quintal shrimp whith price of Rp. $35.000 / \mathrm{kg}$. The collectors receive the harvested product every 2-3 times a week. The income of a fisherman who owns a boat is on average twice the income of those who do not own a boat. With net income of on average $70 \%$ gross income, and on assumption of 25 days of going to the sea, the income of a fisherman who owns a boat is Rp.7.500.000, non owners Rp.5.000.000. Those income are used to pay the cost when the seasonal 'dead water' season occur, that is when the sea water recedes. At the 'dead water' season, fishermen will switch occupation to farmer. However the income of farming is not as much as from hunting fish in the sea. This is the factor why the inhabitant chooses to earn for living from the sea than a higher educational degree. The time and opportunity as the 'dead water' season occur can be used to increase the inhabitant's skills and its processed fish products and also its waste. For example by processing shell's skin into something with economical value, waste water processing before disposal in order to not to polute with pungent odor, creating dried fish packaging that is more suitable with the urban market, etc. Picture 5. Shows the processed sea shell product.

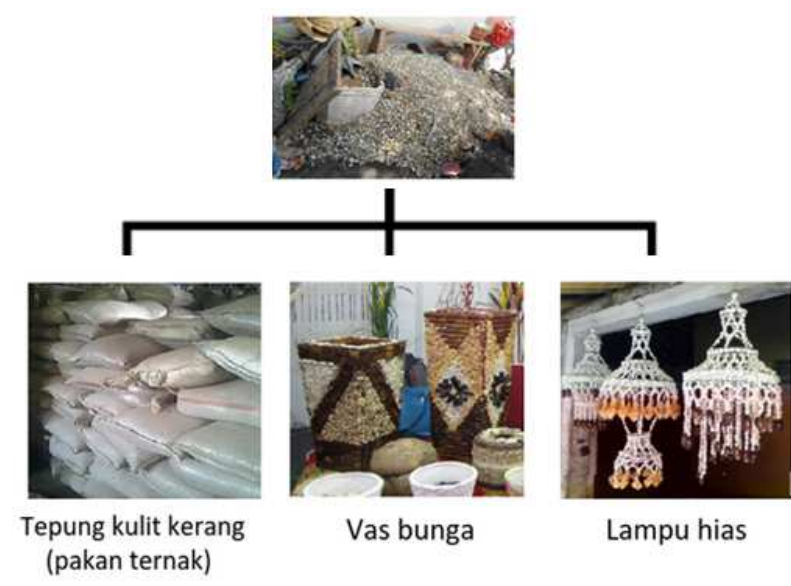

Source: Author's Documentation, 2015

Picture 5. Processed Sea Shell Samples.

Economic activities that empower women in Kalisari's fishermen settlement include making dry fish and salted fish, fish collectoring, sewing, food stalls, making crackers and tempeh, as well as a grocery store and toy packaging services. The type of fish that are proessed are mujair dan gragu. When it is fishing season, the production of dried fish and salted fish may it be gragu or mujair reaches $10 \mathrm{~kg} /$ day. Tailoring and packaging services is a domestic industry that supports the environment. This effort is done while waiting for a shop or stall ( Picture 6 ).

Some permanent residents build boarding room with room rental rates between 300-400 thousand/month. Boarding room with size of $3 \times 4$ meters leased to families of seasonal residents. Based on observations in the field sources, residents who rent a boarding room are mostly married. The conditions of the room is very cramped dorm room, resulting in cooking, washing, drying to be carried out on the terrace / walkway. The cart that is used for selling food parked on vacant land, used collectively (Picture 7). As an itinerant food seller they sell in a residential area around, the wife works as a maid in the area. Both total income between $\mathrm{Rp}$. 1.5 million - 2 million / month, still below the minimum wage of Surabaya.

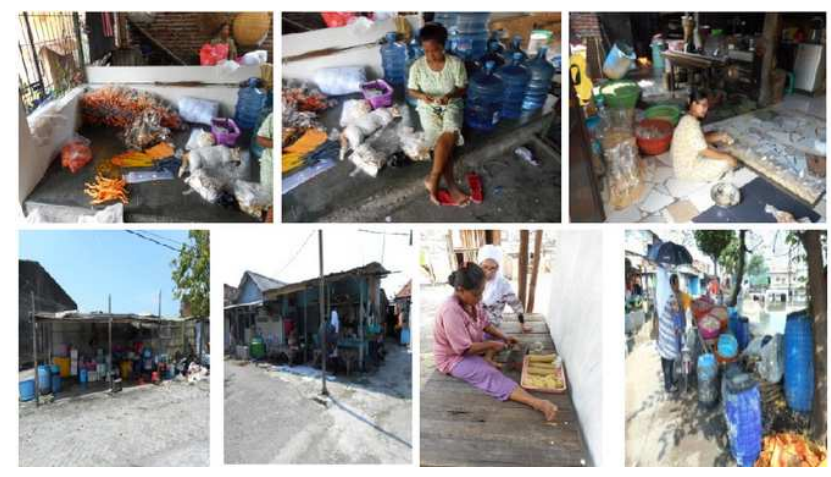

Source: Author's Documentation, 2015

Picture 6. Women's occupation in Kalisari's Fishermen Settlement.

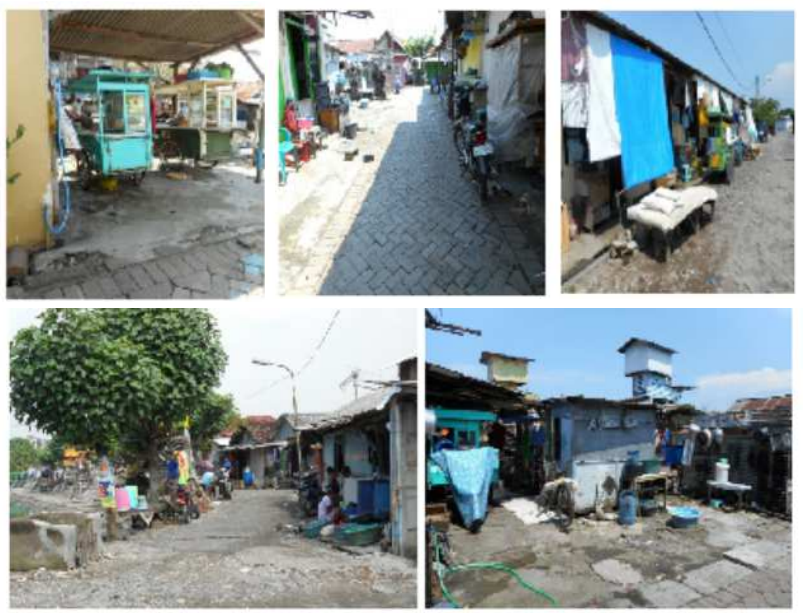

Source: Author's Documentation, 2015

Picture 7. Terrace/Street in Front of the Houses as Family's Activity Place.

\subsubsection{Social Culture}

Usually, a fisherman went to the sea after sunset / evening prayer, and return early morning until the morning. Fresh fish catch is received by collectors that is located not far from the dock. The process of receiving fish from the fishermen is done early morning ( pk . 01.00- 07:00). By collectors of fresh fish is packed / put in boxcooler / thermos sold to the customs at night. The dynamics of fishing activities resulted in the 
fishermen village to be still ' alive ' at night. There are many coffee shops, food stalls and staples remain open at night. The character of the active fishermen village activity throughout the day, turned out to have a positive effect of creating an independent security functions among residents. Shown by the low level of crime or theft. Residents do not refuse and are not afraid to go out at midnight looking for daily needs, as there are shops or stalls open. The atmosphere of the night until the morning fishermen activities seem to come and go into the sea Morning to evening activity dynamics of women processing fish catches (Picture 8 ). The drying is done at the edge of the riverbank. This is because of the unavailability of land around the house due to the high density of buildings . But according to sources in the field, sunning location deliberately kept away from the house because it is the smell factor ( salty ). When it is dry salted fish was brought to the house to be sorted again, then weighed and packed in plastic. Furthermore, after reaching the target of a certain amount, taken by the customer. This process is managed and performed by the wife.

Dried fish processing activities that characterize the fishermen village activities is not well coordinated, disposal of used cleaning fish waste in the yard so that it causes bad odor, No provided means provided at the sunning location, the use of bucket or tub to shelter fish before or after are use scatteredly. Structuring the region should start routine in the smallest neighborhood is home to realize an orderly neighborhoods. Counseling or the provision of material about structuring settlements can be done in a non -formal, given the low level of education and the low level of participation of the population. However, according to sources in the field, voluntary work activities, improvement of the environment, training hard is hard to be held. The reason is because they were so tired from the routine activity for a living. Assistance and counseling tool ever there is no sustainability. What is needed is assistance in carrying out routine quality improvement programs. Appropriate mentoring character Kalisari activities of the fishing village .
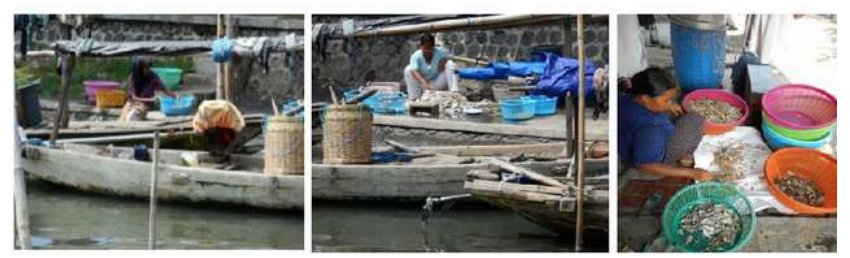

Source: Author's Documentation, 2015

Picture 8. Wife's Activities in Processing Fish.

\subsection{Renewal Strategy of the Settlement}

\subsubsection{Kalisari's Fishermen Settlement Potentials (Opportunities to Renew)}

Potential in the Kalisari village settlements is based on elements and opportunities of sustainability (sustainability opportunities) for renewal, is shown in Table 2 below.

Table 2. Kalisari's Fishermen Settlement Potentials.

\begin{tabular}{|c|c|c|c|}
\hline Element & Potential & Renewal Reasons & Aim of Renewal \\
\hline $\begin{array}{l}\text { Environment } \\
\text { Condition }\end{array}$ & $\begin{array}{l}\text { - There is a river and } \\
\text { drainage channels } \\
\text { - There is a pond area } \\
\text { - Vegetation according } \\
\text { to the character of land }\end{array}$ & $\begin{array}{l}\text { Rivers, drainage channels, ponds and vegetation area special is } \\
\text { the distinctive character possessed by Kalisari fihermen village } \\
\text { that is not contained in the surrounding residential area. Based } \\
\text { on this character, then the Kalisari village has } 2 \text { principle "smart } \\
\text { growth", (1) Distinctive attractive communities with a strong } \\
\text { sense of place } \rightarrow \text { as a fishing village in the city center (2) } \\
\text { preservation of open spaces, farmland, natural beauty and } \\
\text { environmental areas } \rightarrow \text { treating ponds and cleaning the river to } \\
\text { the sea, cultivating plants typical salty water. }\end{array}$ & $\begin{array}{l}\text { To make the fishermen village in Kalisari as } \\
\text { one of the unique tourist village in the middle } \\
\text { of the city with its distinctive character, and } \\
\text { support a series of nautical tourism coastal } \\
\text { areas east of the city of Surabaya. }\end{array}$ \\
\hline $\begin{array}{l}\text { The Building } \\
\text { Physical } \\
\text { Condition }\end{array}$ & $\begin{array}{l}\text { - Permanent and semi- } \\
\text { permanent house } \\
\text { - Type of boarding } \\
\text { houses }\end{array}$ & $\begin{array}{l}\text { The house is the condition of the building which is a part in } \\
\text { determining the quality of housing and the environment. In } \\
\text { order for the environment and good settlement, then the } \\
\text { semi-permanent houses need to be repaired in order to } \\
\text { improve the economy of its inhabitants. One reason for the } \\
\text { emergence of unpermanent home in most of these villages is } \\
\text { uncertainty on the land, so that the owner does not wish to have } \\
\text { a permanent home. So there needs to be an effort of the } \\
\text { government to provide clarity of the status of the land. } \\
\text { Display of boarding house type is also to be improved, so that it } \\
\text { does not look dull by tarpaulins or plastic that are in front of the } \\
\text { house. In addition there needs to be additional kitchen space, } \\
\text { so that is does not look dirty and neat instead. }\end{array}$ & $\begin{array}{l}\text { Unpermanent houses to berepaired in order } \\
\text { the neighborhoods to be better organized. } \\
\text { Similarly, boarding houses, necessary } \\
\text { arrangement in appearance for visual } \\
\text { comfort. This relates to the strategic position } \\
\text { of the village which is close to a residential } \\
\text { area and tourism potential, so renewal needs } \\
\text { to be done. }\end{array}$ \\
\hline $\begin{array}{l}\text { Means and } \\
\text { Facility }\end{array}$ & $\begin{array}{l}\text { - Already have } \\
\text { adequate } \\
\text { infrastructure, but the } \\
\text { sewage is still lacking } \\
\text { - It has a good } \\
\text { environmental } \\
\text { facilities }\end{array}$ & $\begin{array}{l}\text { - Infrastructure that needs be added is a sewer of fish collector } \\
\text { area and the laundry area houses a boarding house so as not to } \\
\text { muddy and smelly. } \\
\text { - Especially for a fish collectors, sewage is the main thing in } \\
\text { order the environment look clean as a fishermen's village } \\
\text { character. }\end{array}$ & $\begin{array}{l}\text { - Dirty water channel corrected to improve } \\
\text { the quality of the neighborhoods in } \\
\text { supporting the distinctive character of a } \\
\text { fishing village. } \\
\text { - With the pedestrian will provide comfort to } \\
\text { the facility means by foot, making the } \\
\text { environment friendly by including vegetation }\end{array}$ \\
\hline
\end{tabular}




\begin{tabular}{|c|c|c|c|}
\hline Element & Potential & Renewal Reasons & Aim of Renewal \\
\hline & $\begin{array}{l}\text { - Special Facility for } \\
\text { fishermen settlement } \\
\text { ( selling fish, a boat } \\
\text { mooring, a fish } \\
\text { drying ) }\end{array}$ & $\begin{array}{l}\text { - Need for a pedestrian to ease towards the means (markets, } \\
\text { schools, clinics). This is consistent with one of the principles of } \\
\text { "smart growth " is "walkable neigborhoods ". From the } \\
\text { fishermen village towards pedestrian infrastructure facilities } \\
\text { are still not available, even that traffic is quite dense. } \\
\text { - There needs to be a fish trading between fishermen and } \\
\text { gatherers representative equipped with a good channel, so it did } \\
\text { not result in pollution of soil and odor. } \\
\text {-There should be made a better fish drying, so as not to cause } \\
\text { odors and be well organized. }\end{array}$ & $\begin{array}{l}\text { shade } \\
\text { - Processing of drainage channels at a fish } \\
\text { collector can create a healthy and comfortable } \\
\text { zone views, so that people around (from a } \\
\text { residential area) are also interested to buy fish } \\
\text { directly from fishermen. } \\
\text { - The drying fish area to be more orderly to } \\
\text { provide a good visual impression on the } \\
\text { settlement. }\end{array}$ \\
\hline $\begin{array}{l}\text { Existing and } \\
\text { Population }\end{array}$ & $\begin{array}{l}\text { - Means of education } \\
\text { - The legality of land } \\
\text { - Documenting } \\
\text { residence status }\end{array}$ & $\begin{array}{l}\text { The settlement location very close to the city center and higher } \\
\text { education institutions, many opportunities and opportunities to } \\
\text { improve the quality of human resources }\end{array}$ & $\begin{array}{l}\text { Improve people's lives Kalisari fishing } \\
\text { villages through education. Environmental } \\
\text { improvements require the active participation } \\
\text { and broad insight }\end{array}$ \\
\hline $\begin{array}{l}\text { Social } \\
\text { Economics }\end{array}$ & $\begin{array}{l}\text { - Fish productivity } \\
\text { - Processed marine } \\
\text { products innovation } \\
\text { marketing system } \\
\text { - Insight in Technology } \\
\text { - Administration and } \\
\text { finance }\end{array}$ & The economy tends to stop at the life routine of fishermen & $\begin{array}{l}\text { Provide additional innovations of creative } \\
\text { effort with assistance from the institution of } \\
\text { higher education. }\end{array}$ \\
\hline Social Culture & $\begin{array}{l}\text { - Society gathering } \\
\text { - Collaboration in } \\
\text { society } \\
\text { - Leadership } \\
\text { - Shared responsibility }\end{array}$ & $\begin{array}{l}\text { Fisherman's family culture does not require their children to } \\
\text { obtain formal education, which is still felt today. Proximity to } \\
\text { city facilities do not have a major impact to utilize these } \\
\text { facilities (schools, shops, offices, etc.) }\end{array}$ & $\begin{array}{l}\text { Forum intensity deliberation residents into } \\
\text { non-formal mentoring mediator acceptable } \\
\text { citizens. For example, by utilizing the } \\
\text { activities of mothers when processing dry } \\
\text { fish, in the Quran recitation event or in a } \\
\text { coffee shop }\end{array}$ \\
\hline
\end{tabular}

Source: Author's Analysis, 2015

\subsubsection{Kalisari's Fishermen Renewal Strategies}

Kalisari's fishermen renewal strategies are conducted based on strategies in "Fishermans Bend Urban Renewal Area", shown in table 3:

Table 3. Kalisari's Fishermen Renewal Strategies.

\begin{tabular}{|c|c|}
\hline Strategy & Steps \\
\hline 1. The creation of 21 st century jobs & $\begin{array}{l}\text { - Attract investment to develop the business of fish (not just dried), such as the activities of home industry for fish } \\
\text { freezing and canning of fish, particularly small fish. } \\
\text { - Promote the creative for the mother - housewife for innovation processed seafood through counseling and } \\
\text { guidance, eg anchovy flour are processed and packaged to be sold }\end{array}$ \\
\hline $\begin{array}{l}\text { 2. The timely provision of } \\
\text { infrastructure }\end{array}$ & $\begin{array}{l}\text { - Consider various funding options to meet the cost of critical infrastructure, such as drainage channel dredging } \\
\text { Kalisari, in order to avoid silting, river fishing boats can go through smoothly without a hitch }\end{array}$ \\
\hline 3. A place that is easy to get around & $\begin{array}{l}\text { - Fixing means that the road to the fishermen village so that it is easily reached by walking, cycling and public } \\
\text { transport } \\
\text { - Make a pedestrian to the pedestrian to the location to provide comfort for visitors and local people. Pedestrian } \\
\text { connects also to public facilities in the surrounding neighborhoods } \\
\text { - Create a strong connection between the river and the sea. }\end{array}$ \\
\hline $\begin{array}{l}\text { 4. A vibrant, mix of uses and } \\
\text { activities }\end{array}$ & $\begin{array}{l}\text { - Build a compact environment to support the activities of fishermen, boat moorings, where loading and unloading of } \\
\text { fish, and the fish sales. }\end{array}$ \\
\hline $\begin{array}{l}\text { 5. Distinctive and diverse } \\
\text { neighbourhoods }\end{array}$ & $\begin{array}{l}\text { - Creating a variety of different environments in accordance with the nature typical fishermen village character, } \\
\text { namely by processing park layout in the form of green spaces along roads and rivers with vegetation typical of } \\
\text { brackish water area ( hibiscus, kerzen ), process the pond area conveniently to go as a means of recreation }\end{array}$ \\
\hline 6. A great place for families & $\begin{array}{l}\text { - Providing decent housing for seasonal residents in the village ( can be either flats ), to improve the physical } \\
\text { condition of the fishing village settlement }\end{array}$ \\
\hline $\begin{array}{l}\text { 7. Strong partnerships and effective } \\
\text { governance }\end{array}$ & $\begin{array}{l}\text { - Provide counseling on credit opportunities soft and simple technology in building healthy occupancy, for the people } \\
\text { of the lower classes. Limited financial resources owned by the local government, then the house should involve } \\
\text { public procurement. In this case the role of local governments as a driving force and facility providers / infrastructure } \\
\text { for housing (facilitator). }\end{array}$ \\
\hline
\end{tabular}




\begin{tabular}{ll}
\hline Strategy & Steps \\
\hline & - Extension of the inventory of heterogeneous (that measures the ability of a family to do the construction or repair of \\
houses in stages), this is to avoid a forced construction activities, thus creating troublesome residents. \\
- Looking for opportunities to get a soft loan facility from a financial institution that is affordable \\
- Extension of the importance of fishing cooperatives, which includes fishing equipment for the welfare of families \\
of fishermen
\end{tabular}

\section{Conclusion}

Kalisari fishermen settlement should be retained. There is need in arrangement of buildings and the environment (infrastructure) so that the area is livable, considering the existing location that is close to the location of the work and fishermen settlements adjacent to the city (own facilities and infrastructure with city standards).

In order to improve the physical condition of the fishermen settlement, the family's economic and socialization needs to be improved. To achieve these objectives required intensive counseling from the government .

Conception of mapping study area still have to demonstrate integrity / balance between " Man - Houses - Nature around ", so that the relationship between the fishermen home and the environment can be dynamic and sustainable ; meaning that it can be developed by citizens .

House procurement system in the study area (associated with the pattern of resource mobilization ) was considered appropriate, when it follows the pattern of society. Said that because the fishing community is largely a newcomer who has a background in traditional culture, so as to be located in urban areas ( state forward / modern), it is necessary to do an act of a merger between the two patterns mentioned above ( traditional and modern), so citizens can fishermen adapt with a new life ( urban ).

Community participation and government is needed for renewal settlement in the fishing village. Without their participation, the renewal strategy will not be able to run well. Rejuvenation strategies must consider how the characteristics of the people who were there, also regard the typical specific characteristics that exist in the physical environment will be able to run well. Renewal strategies must consider how the characteristics of the people who were there, also pay attention to specific characteristics of existing uniqueness.

\section{References}

[1] Basri, Iwan Setiawan. 2009. Perencanaan Lingkungan Permukiman Nelayan Kampung Lere Kota Palu. Jurnal "Mektek" Tahun Xi No.2, 2009.
[2] Budihardjo, Eko. 1983. Arsitektur dan Kota di Indonesia, Alumni, Bandung.

[3] Darmiwati, Ratna. 2001. Perencanaan Permukiman Nelayan di Pantai Timur Surabaya, Jurnal Dimensi Teknik Arsitektur Vol. 29, No. 2, 2001.

[4] Draft Vision. Fishermans Bend Urban Renewal Area 2013. Places Victoria. Melbourne.

[5] Ernawi, Imam S. 2012. Mengintegrasikan Smartgrowth Ke Dalam Sistem Penataan Ruang Indonesia. Berita Penataan Ruang. Direktorat Jenderal Penataan Ruang Kementerian Pekerjaan Umum. [Online] Available: http://www.penataanruang.net/detail_b.asp?id=2065. (March $30,2015)$

[6] Kwanda, Timoticin. 2001. Karakter Fisik Dan Sosial Realestat Dalam Tinjauan Gerakan New Urbanism. Jurnal Dimensi Teknik Arsitektur Vol. 29, No. 1, Juli 2001: 52 - 63. Unika PETRA, Surabaya.

[7] Marwati, Gundhi. 2013. Peremajaan Permukiman Melalui Keswadayaan Masyarakat (Membangun dengan potensi masyarakat di Cigugur Tengah, Cimahi, Jawa Barat). [Online] Available:

https://www.pu.go.id/uploads/services/infopublik2013111912 3742.pdf. (March 30, 2015)

[8] Nasir, Nurvita. 2014. Pengembangan Kota Pesisir terhadap Permukiman Nelayan http:www.slideshare.net/nurvitafnasir/tinjauan-pustaka-permu kiman-nelayan. March 28, 2015.

[9] Paputungan, Muhammad Syahri et.al,. 2014. Arahan Pengembangan Permukiman Nelayan Berbasis Ekowisata (Studi Kasus: Pesisir Pantai Malalayang, Kelurahan Malalayang Satu dan Malalayang Satu Timur, Kecamatan Malalayang, Kota Manado). Jurnal Sabua Vol.6, No.3: 341 349, 2014.

[10] Silas, Johan. 1993. Perumahan: Hunian dan Fungsi Lebihnya, Dari Aspek Sumber Daya dan Eksistensi. Inagural of Professor of Architecture, Fakultas Teknik Sipil dan Perencanaan. Institut Tenologi Sepuluh Nopember. Surabaya.

[11] Sumartinah, Happy Ratna. 2000. Permukiman dan Lingkungan dalam Pengembangan Wilayah. Pidato Pengukuhan Guru Besar Arsitektur. FTSP-ITS. Surabaya.

[12] Turner, John. 1972. Freedom to Build. Collie-Macmiltan Limited, London. 